\title{
EFFECT OF LATEX FROM MUSA PARADISIACA VAR. SAPIENTUM AND CARICA PAPAYA L. ON PROLIFERATION AND MIGRATION FIBROBLAST CELL NIH3T3
}

\author{
ELZA SUNDHANI ${ }^{1,2 *}$, ENDAH NUR IROHIM ${ }^{1,2}$, RUMIYANA HARTININGSIH ${ }^{1,2}$, ERZA GENATRIKA $^{2}$, \\ NUNUK ARIES NURULITA ${ }^{1,2,3}$
}

${ }^{1}$ Cancer and Stem Cells Research Center, Universitas Muhammadiyah Purwokerto, Jl. Raya Dukuhwaluh PO. Box 202 Purwokerto 53182, Central Java, Indonesia. ${ }^{2}$ Department of Pharmacology and Clinical Pharmacy Faculty of Pharmacy, Universitas Muhammadiyah Purwokerto, Jl. Raya Dukuhwaluh PO. Box 202 Purwokerto 53182, Central Java, Indonesia. ${ }^{3}$ Department of Pharmaceutical Chemistry Faculty of Pharmacy, Universitas Muhammadiyah Purwokerto, Jl. Raya Dukuhwaluh PO. Box 202 Purwokerto 53182, Central Java, Indonesia. Email: elzasundhani1991@gmail.com

Received: 04 December 2018, Revised and Accepted: 11 January 2019

ABSTRACT

Objective: The objective of this research was to screen phytochemical constituents and determine the activity of latex from Musa paradisiaca var. sapientum and Carica papaya L. to the process of wound healing in NIH3T3 fibroblasts cells through observations of the proliferation and migration of cells.

Materials and Methods: Screening phytochemical compounds of latex from M. paradisiaca var. sapientum and C. papaya L. used chemical reagent. Cytotoxic activity using 3-(4,5-dimethylthiazol-2-yl)-2.5-diphenyl tetrazolium bromide (MTT) method. The proliferation test used the doubling time method at a susceptible incubation time of $0,24,48$, and $72 \mathrm{~h}$ with a concentration of $25 \mu \mathrm{g} / \mathrm{mL}-250 \mu \mathrm{g} / \mathrm{mL}$. The migration test was carried out using the scratch wound healing method with a concentration of $25 \mu \mathrm{g} / \mathrm{mL}-250 \mu \mathrm{g} / \mathrm{mL}$ in the time range of $0,12,24$, and $48 \mathrm{~h}$.

Results: Phytochemical compounds contained in the latex from M. paradisiaca var. sapientum (saponin and tannin) and C. papaya L. (saponin and alkaloid). The cytotoxic assay results showed that no toxic effect for NIH3T3 fibroblasts cells $\left(\mathrm{IC}_{50}>1000 \mu \mathrm{g} / \mathrm{mL}\right)$. Cell proliferation and migration test results showed an increase in NIH3T3 fibroblast cell proliferation and migration process compared to controls. The concentration of $250 \mu \mathrm{g} / \mathrm{mL}$ of latex from M. paradisiaca var. sapientum and C. papaya L. is the best to increase of proliferation and migration process of NIH3T3 fibroblast cells.

Conclusion: This study concludes that the latex of M. paradisiaca var. sapientum and C. papaya L. has the potential to increase proliferation and migration activity of NIH3T3 cells.

Keywords: Musa paradisiaca var. sapientum, Carica papaya L., NIH3T3, Cell migration, Proliferation.

(c) 2019 The Authors. Published by Innovare Academic Sciences Pvt Ltd. This is an open access article under the CC BY license (http://creativecommons. org/licenses/by/4. 0/) DOI: http://dx.doi.org/10.22159/ijap.2019.v11s5.T0035

\section{INTRODUCTION}

Wounds are a condition of injury to the body caused by contact with physical, chemical, or high-temperature agents. One type of injury that often occurs is the wound caused by sharp objects. Naturally, the body will make repairs after incisions that disrupt the integrity of the skin with stages of hemostasis and inflammation, neovascularization, granulation, reepithelialization, and renovation. However, this requires a long time so that a chemical agent is needed that can help and speed up the healing process of the wound.

One alternative to wound healing agents is to use plants around the environment that are easy to obtain, safe, low cost, and better tolerated by patients [2]. Some active compounds from plants that are proven to help wound healing include tannins, triterpenoids, and alkaloids. Plants containing these compounds and thought to have wound healing activities were Musa paradisiaca var. sapientum and Carica papaya L. M. paradisiaca var. sapientum contains compounds such as tannins, flavonoids, saponins as antibiotics and Vitamin A, Vitamin C, fat, and protein while C. papaya L. also contains saponins, anthraquinones, reducing sugars, flavonoids, alkaloids, tannins, papain, steroids, glycosides, and Vitamin $\mathrm{C}$ which are thought to synergistically be able to stimulate the growth of new cells so that they can help in the healing process of wounds $[3,4]$. Based on previous study, tannins have the ability to precipitate proteins that form clots in wounds, and flavonoids can accelerating tissue regeneration during the process of wound healing $[5,6]$.
Wound healing is defined by the Wound Healing Society as a complex and dynamic as a result of returning the continuity and anatomical function. Wound healing is a tissue regeneration and a complex process in human physiology. The wound healing phase is divided into three phases, namely, the inflammatory phase, the proliferation phase, and the remodeling phase. Fibroblasts play an essential role in the process of fibroplasia which is the stage of new blood vessel formation, migration, and proliferation of fibroblasts, extracellular matrix deposition, and maturation and organization of fibrous tissue (remodeling) [7]. At present, there are many wound healing products developed by the pharmaceutical industry but are still unsatisfactory due to the long process, high costs, and various adverse side effects [8]. This study was designed to see the ability of latex from M. paradisiaca var. sapientum and C. papaya L. to induce proliferation and migration of N1H3T3 fibroblast cells which is a mechanism for wound healing and to identify the compounds contained in the latex of the two plants that play a role in the wound healing process.

\section{MATERIALS AND METHODS}

\section{Materials}

The tools used in this study include glassware, analytical balance, autoclave, Labconco Purifier Class II biosafety cabinet, $\mathrm{CO}_{2}$ incubator, liquid nitrogen, inverted microscope, hemocytometer (Neubauer improved $0.100 \mathrm{~mm}$ Tiefe Depth Profondeur $0.0025 \mathrm{~mm}^{2}$ ), and enzymelinked immunosorbent assay (ELISA) reader. The main ingredients used in this study were latex from M. paradisiaca var. sapientum and C. papaya L. Material analysis of chemical compounds includes $\mathrm{HCl}$, 
Mg powder, 1\% FeCl3, sulfuric acid, H2SO4, Mayer, Dragendorff, and Wagner reagent.

Cell culture materials used are cell growth media, Dulbecco's Modified Eagle's Medium (DMEM) containing fetal bovine serum 10\% v/v, penicillin-streptomycin $1 \% \mathrm{v} / \mathrm{v}$, and fungizone $0.5 \% \mathrm{v} / \mathrm{v}$. Harvesting cells from tissue culture dish using trypsin-ethylenediaminetetraacetic acid (EDTA) were $0.25 \%$. The material used in cell proliferation and migration testing is 3-(4,5-dimethylthiazol-2-yl)-2.5diphenyltetrazolium bromide (MTT) reagent concentration of $5 \mathrm{mg} / \mathrm{ml}$ dissolved in phosphate-buffered saline (PBS) $1 \times \mathrm{pH}$ 7.4. Work reagents are made by diluting 10 times the stock reactant using DMEM. The stopper used is sodium dodecyl sulfate (SDS) $10 \%$ in $\mathrm{HCl} 0.1 \mathrm{~N}$. PBS $1 \times \mathrm{pH} 7.4$ is made by dissolving $8 \mathrm{~g} \mathrm{NaCl}, 0.2 \mathrm{~g} \mathrm{KCl}, 0.2 \mathrm{~g} \mathrm{KH} 2 \mathrm{PO} 4$, and $1.15 \mathrm{~g} \mathrm{Na} 2 \mathrm{HPO} 4$ into $1 \mathrm{~L}$ of aquabides.

\section{Methods}

Plant identification

The identification of M. paradisiaca var. sapientum and C. papaya $\mathrm{L}$. was carried out at the Plant Taxonomy Laboratory, Faculty of Biology, Jenderal Soedirman University, Purwokerto.

\section{Material collection}

Preparation and collection of materials, the latex of M. paradisiaca var. sapientum was obtained from Panerusan Village, Wonosobo, Central Java, Indonesia. The latex is taken by cutting the midrib from M. paradisiaca var. sapientum trees with a height of $1.5 \mathrm{~m}$ close to the parent tree and then accommodated in a clean glass place. While the latex of C. papaya L. was taken from the village of Bulupayung, Kesugihan District, Cilacap Regency, Central Java, Indonesia. Taking latex of $C$. papaya $\mathrm{L}$. is done every week to get new latex because the time to survive latex is about 3-5 days. Taking latex of $C$. papaya $\mathrm{L}$. is done by cutting the papaya leaf stems. The latex of M. paradisiaca var. sapientum and C. papaya $\mathrm{L}$. is taken using a knife and a container that has been cleaned using $70 \%$ ethanol to maintain sterilization from the knife and container used. The best time to take latex is in the morning; this is because, in the morning, the resulting latex is more and better [1].

\section{Sample preparation}

The latex of M. paradisiaca var. sapientum and C. papaya L. is dissolved in $1 \%$ dimethyl sulfoxide. From the mother liquor then diluted with DMEM culture media.

\section{Screening phytochemical compounds}

Identification of phytochemicals compound is using reagent specific for saponins, tannins, flavonoids, and alkaloids. Identification is made by observing the change in color of the sample added to the reagent.

\section{N1H3T3 fibroblast cell culture}

All tools that will be used are sterilized first. DMEM culture media made $3 \mathrm{ml}$ aliquots in a conical tube. Cells are taken from the liquid nitrogen tank, then immediately thawed in a water bath at $37^{\circ} \mathrm{C}$. The cell suspension was centrifuged at a speed of $650 \mathrm{rpm}$ for $3 \mathrm{~min}$ and then the supernatant was removed. In the cell deposits, new media are added and suspended slowly until homogeneous. Then, the cells were grown in several tissue culture flasks or tissue culture dishes; each of which was $2 \mathrm{ml}$ and added with $5 \mathrm{ml}$ of culture medium and homogenized. The cell condition was observed under a microscope and then incubated in a $\mathrm{CO}_{2}$ incubator at $37^{\circ} \mathrm{C}$ with $5 \% \mathrm{CO}_{2}$ flow. Twentyfour hours later, a culture media were replaced, then cells were grown to confluent, and the amount was sufficient for research.

After confluent cells, the media were removed, and the cells were washed PBS twice. Cells were added $500 \mu \mathrm{l}$ trypsin-EDTA $0.25 \%$ to release cells and then incubated for 3-5 min in a $\mathrm{CO}_{2}$ incubator. The DMEM media are added to the tissue culture dish or flask and cells resuspended until all of them are removed from the wall of tissue culture dish or flask. The cell suspension is then transferred into a new sterile conical tube. Cells are calculated by a hemocytometer and cell counter.

\section{MTT assay}

MTT assay used to know the half maximal inhibitory concentration $\left(\mathrm{IC}_{50}\right)$ from the latex of M. paradisiaca var. sapientum and C. papaya $\mathrm{L}$. The cell concentration with NIH3T3 fibroblasts $5 \times 10^{3}$ cells distributed into the 96-well plate and incubation for $24 \mathrm{~h}$ at $37^{\circ} \mathrm{C}$ and $5 \% \mathrm{CO}_{2}$; then, the sample was added as much as $100 \mu$ for each concentration variation from the sample. At the end of incubation $(24 \mathrm{~h})$, the culture medium containing the sample was removed, then washed with $100 \mathrm{ml}$ PBS, and then into each well was added $100 \mathrm{ml}$ of DMEM culture media containing MTT $0.5 \mathrm{mg} / \mathrm{ml}$, incubated again for $4-6 \mathrm{~h}$ at $37^{\circ} \mathrm{C}$ with $\mathrm{CO}_{2}$ flow. Living cells will react with MTT to form purple formazan crystals. After 4-6 h, the media containing MTT is removed; then, 10\% SDS solution is added to dissolve formazan crystals. Cells were incubated overnight at room temperature and protected from light. At the end of incubation, the plate is shaken horizontally (with a shaker) for $3 \mathrm{~min}$ then read by ELISA reader at $\lambda 595 \mathrm{~nm}$.

\section{Cell proliferation test}

The proliferation of N1H3T3 fibroblast cells was detected by MTT assay. Briefly, $180 \mu \mathrm{l}$ of $3 \times 10^{5} \mathrm{cells} / \mathrm{ml}$ is inserted into 24 wells. Incubated overnight at $37^{\circ} \mathrm{C}$ and $5 \% \mathrm{CO}_{2}$, then the sample was added as much as $20 \mu \mathrm{l}$ for each concentration variation from the sample, incubated for $0,24,48$, and $72 \mathrm{~h}$ and media control and cell control at $37^{\circ} \mathrm{C}$ and $5 \%$ $\mathrm{CO}_{2}$. Percent viability cell is calculated based on the sample absorbance of each well at ELISA reader at $595 \mathrm{~nm} \lambda$

\section{Cell migration test N1H3T3}

Fibroblast cells were cultured and cultured in 24 wells. Then, it was injured by being scratched using the help of $10 \mu \mathrm{l}$ micropipette tip by moving back and forth over the medium; the wound made $0.5 \mathrm{~mm}$ long. The well is then washed with PBS for $3 \mathrm{~h}$ to remove cell impurities. Then, the wound is seen with the help of a reverse phase microscope equipped with a digital camera. Add $20 \mu \mathrm{l}$ of the variation in sample concentration into the culture medium and control with PBS. The migration of fibroblast cells was photographed $24 \mathrm{~h}$ after being treated with wounds. Photo taking is done at $0-24 \mathrm{~h}$. The distance of cell migration in cells treated by the addition of samples is compared to the distance of migration of control cells; then, migration is calculated (Manoj et al., 2009).

Table 1: Phytochemical compounds

\begin{tabular}{|c|c|c|c|c|}
\hline $\begin{array}{l}\text { Chemical } \\
\text { compound }\end{array}$ & $\begin{array}{l}\text { Latex Musa paradisiaca } \\
\text { var. sapientum }\end{array}$ & Latex Carica papaya L. & $\begin{array}{l}\text { Latex Musa paradisiaca } \\
\text { var. sapientum }\end{array}$ & Latex Carica papaya L. \\
\hline Saponin & Steady foam & Steady foam & Positive & Positive \\
\hline Tannin & Dark blue & Light brown & Positive & Negative \\
\hline \multicolumn{5}{|l|}{ Alkaloid } \\
\hline Dragendorff & - & Not formed deposits & Negative & Negative \\
\hline Mayer & Not formed deposits & White deposits & Negative & Positive \\
\hline Wagner & Not formed deposits & Deposits of brownish red & Negative & Positive \\
\hline Flavonoid & Not color & Not color & Negative & Negative \\
\hline
\end{tabular}




\section{RESULTS AND DISCUSSION}

Identification of phytochemical compounds of latex from M. paradisiaca var. sapientum and C. papaya L. shown in Table 1.

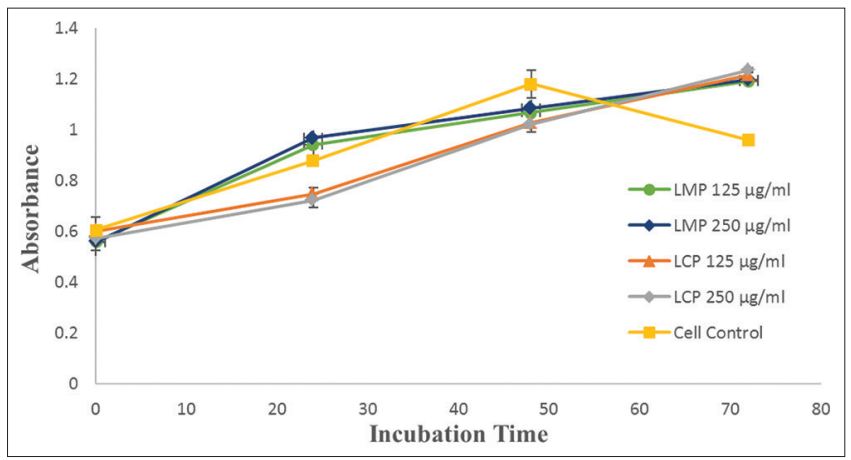

Fig. 1: NIH3T3 fibroblast cell proliferation test graph grown on 96-well plate and treated with a latex of Musa paradisiaca var. sapientum (LMP) and Carica papaya L. (LCP) with a series of concentrations of $50 \mu \mathrm{g} / \mathrm{ml}, 125 \mu \mathrm{g} / \mathrm{ml}$, and $250 \mu \mathrm{g} / \mathrm{ml}$
Latex from $M$. paradisiaca var. sapientum and $C$. papaya L. contains saponins, indicated with the formation of foam. Saponin is one of the compounds that trigger the formation of collagen that plays a role in wound healing [9]. Besides, saponins also have the ability as a cleanser is useful for healing a wound [10]. Saponins are active compounds that can cause the foam if beaten with water [11]. Tannin is a compound that has a therapeutic effect as an antiseptic wound tissue - latex from M. paradisiaca var. sapientum gave positive results with a dark blue color formation, while the latex from $C$. papaya $\mathrm{L}$. showed a negative result due to light brown color formed. The color change occurs when the addition of $\mathrm{FeCl}_{3}$ due to reaction with one hydroxyl group on tannins [12]. Tannins serve as an astringent which can cause small skin pores, stop the exudate and light bleeding [2]. The alkaloid is an organic base containing nitrogen $(\mathrm{N})$ is generally derived from the plant, which has a powerful physiological effect against human beings. The benefits of an alkaloid in the field of pharmacology are to fight microbial infections (Pasaribu, 2009). Alkaloids have the ability as an antibacterial, achieved using disrupting the peptidoglycan constituent components in bacterial cells, making cell walls do not wholly form and cause cell death [10]; on the test, latex alkaloids from $M$. paradisiaca var. sapientum give negative results, and latex from $C$. papaya L. shows positive results.

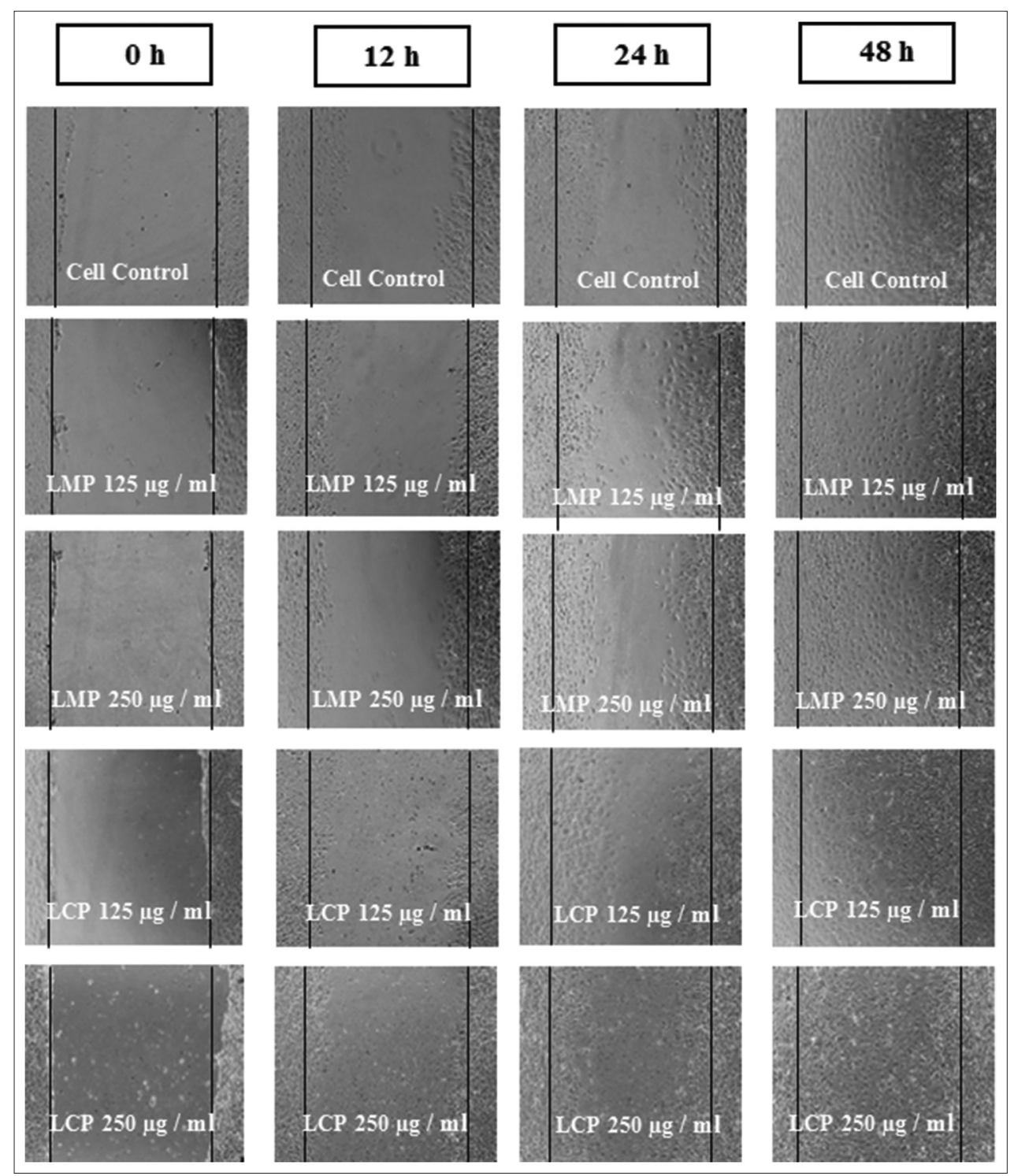

Fig. 2: NIH3T3 fibroblast cell migration test latex of Musa paradisiaca var. sapientum (LMP) and Carica papaya L. (LCP) 
The cytotoxic test was carried out aimed to determine the cytotoxic potential of latex from M. paradisiaca var. sapientum and C. papaya $\mathrm{L}$. against cell NIH3T3. The method used in the cytotoxic test is using the MTT assay. MTT assay is a method based on the ability to live cells to reduce MTT salts. The principle of the MTT method is the reduction of MTT tetrazolium yellow salt (MTT) by the reductase system. Tetrazolium succinate which is included in the respiratory chain in the mitochondria of living cells forms purple formazan crystals and is not water soluble [13]. The results obtained in the cytotoxic test are in the form of $\mathrm{IC}_{50}$ values. The $\mathrm{IC}_{50}$ value indicates the concentration of the test compounds which can provide a cell viability barrier of $50 \%$ of the total cell number - the $\mathrm{IC}_{50}$ value of latex from M. paradisiaca var. sapientum and C. papaya L. was analyzed using Microsoft Excel program, which was $2.801 \mu \mathrm{g} / \mathrm{mL}$ and $6.280 \mu \mathrm{g} / \mathrm{mL}$. From the $\mathrm{IC}_{50}$ value obtained in the cytotoxic test, it can be seen that the latex from M. paradisiaca var. sapientum and C. papaya $\mathrm{L}$. does not have a toxic effect because it has an $\mathrm{IC}_{50}$ value of more than $1000 \mu \mathrm{g} / \mathrm{mL}$ [14] so that it has the potential for NIH3T3 fibroblast cell.

In the cell proliferation test is performed by doubling time. Doubling time is a period needed by cells to be able to make the amount double the original number [15]. In this proliferation test, the lower the concentration of latex used, the better the activity in healing wounds. The longer the incubation period, the more fibroblast cells proliferate well. This is proven by the concentration of $50 \mu \mathrm{g} / \mathrm{mL}$ which has a more proliferative nature compared with concentrations of $125 \mu \mathrm{g} / \mathrm{mL}$ and $250 \mu \mathrm{g} / \mathrm{mL}$. The following is the result of the proliferation of latex from M. paradisiaca var. sapientum and C. papaya L. (Fig. 1).

Determination of the ability of NIH3T3 fibroblast cell migration is done by quantifying the width of the scratch at the beginning of the scratching until the cells migrate to cover the scratches. From the migration of fibroblast cells treated with latex from M. paradisiaca var. sapientum and C. papaya L. with concentrations of $50 \mu \mathrm{g} / \mathrm{ml}, 125 \mu \mathrm{g} / \mathrm{ml}$, and $250 \mu \mathrm{g} / \mathrm{ml}$ so that the higher the concentration of latex and the longer the incubation period of the latex from M. paradisiaca var. sapientum and $C$. papaya L. can help the NIH3T3 fibroblast cell migration process. Proliferation and migration of fibroblasts play an essential role in the formation of granulation tissue and wound closure [16]

At $0 \mathrm{~h}$, the fibroblast cells grown on the 24-well plate were scratched using yellow, sterile tips. At $12 \mathrm{~h}$, the scratched fibroblast cells begin to fuse and begin to stick to the plate again due to the response between cells with each other. At the $24^{\text {th }} \mathrm{h}$, the scratches begin to shrink, and it is clear that the process of fibroblast cell migration is caused by the growth factor that will trigger the cell to approach. At $48 \mathrm{~h}$, the scratches began to close, and at a concentration of $250 \mu \mathrm{g} / \mathrm{ml}$, the scratches were closed, but there were not many cells. When compared with concentrations of $50 \mu \mathrm{g} / \mathrm{ml}$ and $125 \mu \mathrm{g} / \mathrm{ml}$, the scratch distance at a concentration of $250 \mu \mathrm{g} / \mathrm{ml}$ was smaller, as well as at a concentration of $125 \mu \mathrm{g} / \mathrm{ml}$, the scratch distance of cells was smaller than the concentration of $50 \mu \mathrm{g} / \mathrm{ml}$. This shows that the higher the concentration of latex from M. paradisiaca var. sapientum and C. papaya $\mathrm{L}$., the more it will be able to help the migration process of NIH3T3 fibroblast cells. The migration results can be shown in Fig. 2 .

Cell proliferation has an essential role in the process of wound healing; this is because cell proliferation is a phase where the formation of new tissue that connects cells originating from the mesenchyme the latex from M. paradisiaca var. sapientum was applied topically in the form of fresh latex, in the process of wound healing using mice test animals. The latex accelerates the process of recapitalizing epidermal tissue, forming new blood vessels (neocapillarization), forming connective tissue (fibroblasts), and infiltrating inflammatory cells in the wound area [17]. This indicates that the latex from M. paradisiaca var. sapientum affects the proliferation of fibroblast cells where the more cells proliferate, the faster the wound healing process. This is influenced by the compounds contained tannins, saponins, and flavonoids. Tannin, saponins, and flavonoids function as antibiotics and stimulate the growth of new cells in the wound [18]. Gurung and Basnet conducted wound healing tests in rats using latex of C. papaya L. can be used to help heal wounds in mice [19]. Papain and chymopapain are known to be useful as antimicrobials and antioxidants. Ajani and Ogunbiyi also researched papaya latex used to help heal wounds in diabetic rats. The result is that papaya latex can help wound healing more than gentamicin, normal saline, and propylene glycol [1].

\section{CONCLUSION}

This study concludes that the latex of M. paradisiaca var. sapientum and C. papaya L. has the potential effect to help the wound healing process by induction of proliferation and migration on NIH3T3 fibroblast cell.

\section{ACKNOWLEDGMENT}

The authors are highly grateful to financial support from LPPM Universitas Muhammadiyah Purwokerto.

\section{CONFLICTS OF INTEREST}

All authors have none to declare.

\section{REFERENCES}

1. Ajani RS, dan Ogunbiyi KI. Carica papaya latex accelerates wound healing in diabetic Wistar rats. Eur J Med Plants 2015;9:1-12.

2. Anief M. Topical Drug Formulations by Skin Diseases. Yogyakarta: UGM Press; 1997.

3. Fauzan F, Mardiyan KE, Widjiati W. Administering topical leaf extract of papaya (Carica papaya L) on murine experimental animals (Mus musculus) pregnant increases collagen density vaginal tissue. Majalah Obstet Ginekol 2015;23:118-27.

4. Pongsipulung RG, Paulina YV, dan Yos B. The Formulation and Testing of Pisang Ambon Extract Ointment (Musa paradisiaca var. Sapientum (1.) Against the Open Sores on the Skin of a White Male Wistar Strain Rats (Rattus norvegicus). Manado: Studi Farmasi FMIPA UNSRAT. Farmasi POLTEKES; 2012.

5. Okoli RI, Aigbe O, Ohaju O, Mensah JK. Medicinal herbs used for managing some common ailments among esan people of Edo state, Nigeria. Pak J Nutr 2007;6:490-6.

6. Wijayanto. The Difference in Speed the Healing of Wounds With Sayat Brand of Green Tea 6 Concentration, Povidone Iodine and $4 \mathrm{gr} \%$ on Mice. Malang: Universitas Muhammadiyah Malang; 2009.

7. Oky M, Manjas M, Putra AE, Agus S. Influence of fluid filtrate culture fibroblasts (CFF) of wound healing; experimental research on strain Wistar Rattus norvegicus. Andalas J Health 2012;1:1-13.

8. Kumar B, Vijayakumar M, Govindarajan R, Pushpangadan P. Ethnopharmacological approaches to wound healing exploring medicinal plants of India. J Ethnopharmacol 2007;114:103-13.

9. Suratman, Sumiwi SA, dan Gozali D. Influence of extracts of antana in the form of ointments, ktim, and Jelly towards healing burns. Cermin Dunia Kedokt 1996;108:31-6.

10. Robinson T. Kandungan Organik Tumbuhan Tinggi. Translated: Padmawinata, K. Bandung: Penerbit ITB; 1995.

11. Padmasari PD, Astuti KW, dan Warditiani NK. Phytochemical screening $70 \%$ ethanol extract of the rhizome bangle (Zingiber purpureum Roxb.). J Farmasi Udayana 2013;2:1-4.

12. Mahatriny NN, Payani NP, Oka IB, Astuti KW. Phytochemical screening of ethanol extracts of leaves of Papaya (Carica papaya L.) was obtained from the area of Ubud, Gianyar, Bali. J Farmasi Udayana 2014;13:11-2

13. Cancer Chemoprevention Research Center. Cytotoxic Test of MTT Method; 2013. Available from: http://www.ccrc.farmasi.ugm.ac.id. [Last accessed on 2018 Jul 12].

14. Ira D. Cytotoxic test of $70 \%$ ethanol extract of herba cemplukan (Physalis angulata Linn.) against WiDr cells. Journal Kimia Valensi 2008;1:149-56.

15. Mader SS. Human Biology. Lowa: McGraw Hill; 2000.

16. Kusumawardhani AD, Kalsum U, dan Rini IS. Effect of betel leaves extracts ointment (Piper betle Linn.) on the number of fibroblast in IIA degree burn wound on rat (Rattus norvegicus) Wistar strain. Majalah Kesehatan FKUB 2015;2:16-28.

17. Listiyani AR. The Effect of the Giving of the Latex from 
Musa paradisiaca var. Sapientum in the Process of Wound Healing in Mice (Musculus albinus). Thesis. Bogor: Fakultas Kedokteran Hewan, Institut Pertanian; 2006.

18. Priosoeryanto BP, Huminto H, Wientarsih I, Estuningsih S. Banana Tree Stem Sap Activity in the Process of Wound Healing and Kosmetiknya
Effects on animals. Lembaga Penelitian dan Pemberdayaan Masyarakat. Bogor: Institut Pertanian Bogor; 2006.

19. Gurung S, Skalko-Basnet N. Wound healing properties of carica papaya latex: In vivo evaluation in mice burn model. J Ethnopharmacol 2009;121:338-41. 